\title{
Comparative Studies on the Nutrients, Sensory and Storage Qualities of Moon-Fish (Citharinus citharus Geoffery Saint-Hilaire 1809) Pre-Treated with Extracts from Two Spices
}

Agbabiaka LA ${ }^{1 *}$, Kuforiji $\mathrm{OA}^{2}$ and Egobuike $\mathrm{CC}^{3}$

${ }^{1}$ Department of Fisheries Technology, Federal Polytechnic Nekede Owerri, Imo State, Nigeria

${ }^{2}$ Department of Agricultural Technology, Federal Polytechnic Ekowe, Bayelsa State, Nigeria

${ }^{3}$ Department of Fisheries Technology, Imo State Polytechnic, Umuagwo-Ohaji, Imo State, Nigeria

\begin{abstract}
Comparative effects of soaking Citharinus citharus with extracts from two spices (Black pepper=Piper guineense and Ginger=Zingiber officinale) prior to oven drying using Nutrients and Organoleptic assessments as parameters were studied. Seventy two freshly caught Moonfish weighing $875 \pm 25 \mathrm{~g}$ were killed, weighed, gutted and washed thoroughly with portable tap water and were divided into two batches of 36 fish each. Each batch was sub-divided into 3 groups of 12 fish per treatment made up of a triplicate, i.e., 4 fish per replicate in a completely randomized design. The fish in first batch was divided into 3 treatments of 12 fish and were immersed for 30 minutes in composite solution containing $3 \%$ brine and extract of Piper guineense at $0 \%, 2 \%$ and $5 \%$ concentration coded as $\mathrm{BP}_{0}, \mathrm{BP}_{2}$ and $\mathrm{BP}_{5}$ respectively; the control treatment contained no Black pepper $\left(\mathrm{BP}_{0}\right)$. Similar operations were carried out on the second batch of fish soaked in composite solution containing same concentration of brine as hitherto but with varying concentration of ginger extract (Zingiber officinale) at $0 \%, 2 \%$ and $5 \%$ for 30 minutes coded as $\mathrm{GE}_{0}, \mathrm{GE}_{2}$ and $\mathrm{GE}_{5}$ respectively; the control treatment was soaked in $3 \%$ brine only without ginger extract $\left(\mathrm{GE}_{0}\right)$. All fish pre-treated were allowed to drain for five minutes, oven-dried for 5 hours at the temperature range of $80^{\circ} \mathrm{C}-90^{\circ} \mathrm{C}$ and allowed to cool at room temperature. Results from proximate analysis showed that the use of composite mixture of brine and spices extract increased the crude protein (CP) content of fish linearly $(p<0.05)$, there was no significant differences $(p>0.05)$ in sensory qualities between the two experiments pre-treated with black pepper and ginger. These data above indicated that fish pre-treated with composite solutions of brine and extract of two spices (Piper guineense and Zingiber officinale) prior to oven drying have potentials to improve nutrients assay and storage qualities on Moonfish.
\end{abstract}

Keywords: Moonfish; Comparative; Nutrients; Organoleptic; Spices and storage

\section{Introduction}

Fish contribute more than $60 \%$ of the world supply of protein, especially in the developing countries including Nigeria [1]. It has been reported that Nigeria as a maritime nation with a vast population estimated at over 160 million people and a coastline measuring approximately 853 kilometers [2], with huge fish production capacity to contribute significantly to the agricultural sector spends over $\$ 200$ million on fish importation annually. The recent importation rate is over 750,000 metric tonnes [3,4] but the annual fish demand in the country was estimated at about 2.66 million metric tonnes, while a paltry domestic production is estimated to be 780,000 tonnes; the demand-supply gap stands at a staggering 1.8 million metric tonnes. Despite the popularity of farming in Nigeria, the fish farming industry can best be described as being at the infant stage when compared to the large market potential for its production and marketing [5].

The right step currently geared towards reducing the demandsupply deficit for fish (Aquaculture development) may not be realistic until appropriate measures towards curtailing post-harvest losses and quality depreciations are put in place through improved value-addition on processed products [6,7]. The high ambient temperature in Nigeria typical of the tropics that often encourages food/fish spoilage has made it imperative to search for alternative economical method(s) other than cold storage hindered by high energy cost occasioned by incessant power outage in developing nations to improve post-harvest/ shelf-life of fish. Many processing methods have been adopted with successes but use of spices on smoke-dried fish is yet to be commercialized in Nigeria.

Moonfish (Citharinus citharus) is a genus of lute fish from tropic
Africa with six currently described species. Moonfish belongs to the family Citharinidae and are found in most habitats but they are particularly abundant in swamp, creeks and lakes in Nigeria [8]; where they spawn during the flood season. Their deep and flattened body earned them the popular name Moonfish [9]. The species is relatively cheap comparatively but a highly nutritious fish when cooked, smoked or dried. Proximate composition of the moonfish revealed that it contained $77.1 \%$ moisture, $0.98 \%$ Lipid, $20.4 \%$ crude protein and $1.5 \%$ ash [8].

Spices such as Black pepper (Piper guineense) and Ginger (Zingiber officinale) have been natural additives for more than 2000 years. Studies have shown that, the long term dietary intake of ginger has hypoglycemic and hypo-lipidaemic effect [10], while the seeds of black pepper are put into variety of uses, for instance in some parts of Nigeria, the seeds are consumed by women after child birth to enhance uterine contraction for expulsion of placenta and remains from the womb [11]. In order to guarantee abundant and sustainable fish supply, there is need to reduce

*Corresponding author: Agbabiaka LA, Department of Fisheries Technology Federal Polytechnic Nekede Owerri, Imo State, Nigeria, Tel: 083431 501; E-mail: adegokson2@yahoo.com

Received July 27, 2015; Accepted November 06, 2015; Published February 15, 2016

Citation: Agbabiaka LA, Kuforiji OA, Egobuike CC (2016) Comparative Studies on the Nutrients, Sensory and Storage Qualities of Moon-Fish (Citharinus citharus Geoffery Saint-Hilaire 1809) Pre-Treated with Extracts from Two Spices. J Aquac Res Development 7: 398. doi:10.4172/2155-9546.1000398

Copyright: (c) 2016 Agbabiaka LA, et al. This is an open-access article distributed under the terms of the Creative Commons Attribution License, which permits unrestricted use, distribution, and reproduction in any medium, provided the original author and source are credited. 
Citation: Agbabiaka LA, Kuforiji OA, Egobuike CC (2016) Comparative Studies on the Nutrients, Sensory and Storage Qualities of MoonFish (Citharinus citharus Geoffery Saint-Hilaire 1809) Pre-Treated with Extracts from Two Spices. J Aquac Res Development 7: 398. doi:10.4172/2155-9546.1000398

Page 2 of 5

spoilage and increase storage qualities/shelf life. Therefore, this work is aimed at determining the suitability of using spices (Piper guineense and Zingiber officinale) which have been reported to contain anti-microbial, anti-oxidant and anti-septic qualities/properties in improving the shelf life of moonfish and consumers' acceptability $[12,13]$.

\section{Materials and Method}

\section{Site of experiment}

This experiment was carried out at the Department of Food Science and Technology, Imo State Polytechnic Umuagwo-Ohaji Nigeria Umuago-Ohaji lies between latitude $5^{\circ} 17^{1}$ and $5^{\circ} 19^{1} \mathrm{~N}$, longitude $7^{\circ} 54^{1}$ and $6^{\circ} 56^{1}$ E. It is twenty six kilometres from the State capital (Owerri) on the Port Harcourt road.

\section{Collection of samples}

Seventy two (72) freshly caught Moonfish (Citharinus citharus) weighing between 850-900 g were purchased from Swale Market in Yenegoa, Bayelsa State, Nigeria. Some quantity of dried black pepper seeds and ginger rhizomes were bought at Ekeonunwa Market in Owerri, Imo State.

\section{Preparation of samples}

Dried Black pepper seeds and Rhizome of Ginger were ground into powder using kitchen grinding machine respectively. Seventy two freshly caught Moonfish weighing $875 \pm 25$ g were killed, weighed, gutted and washed thoroughly with portable water and were divided into two batches of 36 fish each. Each batch was sub-divided into 3 groups of 12 fish per treatment in a triplicate, i.e., 4 fish per triplicate in a completely randomized design. First treatment was immersed in $3 \%$ brine without spice extract (control), second treatment was soaked in solution of $3 \%$ brine and $2 \%$ black pepper extract, while the third treatment was also immersed in the solution of $3 \%$ brine and $5 \%$ black pepper extract respectively for 30 minutes coded $\mathrm{BP}_{0}, \mathrm{BP}_{2}$ and $\mathrm{BP}_{5}$. Similar procedure were carried out on the second batch of fish soaked in composite solution containing same concentration of brine and varying concentration of ginger extract (Zingiber officinale) at $0 \%$, $2 \%$ and $5 \%$ for 30 minutes coded as $\mathrm{GE}_{0}, \mathrm{GE}_{2}$ and $\mathrm{GE}_{5}$ respectively; the control treatment was soaked in $3 \%$ brine only without ginger extract $\left(\mathrm{GE}_{0}\right)$. The spice extracts were obtained by soaking appropriate quantity of ground spices (black pepper and ginger) respectively in water overnight and sieved accordingly. Thereafter, fish samples soaked in the composite solutions of brine/spice extracts respectively for 30 minutes were removed and put into separate baskets covered with muslin cloth to drain for 5 minutes. Subsequently, the fish samples were arranged into labelled trays inside gas oven and allowed to dry at temperature of $80^{\circ} \mathrm{C}-90^{\circ} \mathrm{C}$ for 5 hours.

\section{Processing techniques}

Drying was conducted by using gas oven. The pre-treated fish samples were arranged on the oven trays and allowed to dry for 5 hours, during which turning over of the fish were done at interval to achieve uniformly dried product. Thereafter, the dried product were removed from the oven and arranged on separately labelled trays and were allowed to cool at room temperature before weighing in order to determine the moisture loss. Labelled samples were accordingly and carefully stored for 7 days in quality control room during which time, daily monitoring (8:00-9:00 hours) was conducted to check the effect of the spices on the shelf life and organoleptic qualities of the fish.

\section{Proximate and storage analysis}

Samples of oven-dried Moonfish were collected from the treatments on triplicate basis within 24 hours for the nutrients assay such as crude protein (Kjeldhal procedure), lipid (Soxhlet method), Ash (flame photometric) as described by AOAC [14]. The samples were stored 7 days at ambient temperature and were monitored daily between the hours of 8:00-9:00 (CAT) in order to determine the effect of the spices on the shelf life.

\section{Organoleptic evaluation}

The samples of the oven-dried fish were served to 10 (ten) trained panelists made up of Staff and Students of Department of Nutrition and Food and Technology, Imo State Polytechnic Umuagwo; who were familiar with assessing the sensory attributes such as aroma, taste, appearance/colour, consistency and general acceptability. Nine points hedonic scale ( $9=$ excellent; $8=$ very good; $6=$ good; $4=$ fair; $2=$ =poor; and $0=$ bad) was adopted according to Afolabi et al. [15] to evaluate changes in colour, aroma, taste and texture of fish.

The samples in batch $\mathrm{A}$, pre-treated with black pepper at $0 \%, 2 \%$ and $5 \%$ concentration were coded as $\mathrm{BP}_{0}, \mathrm{BP}_{2}$ and $\mathrm{BP}_{5}$ respectively while Ginger pre-treated samples were coded as $\mathrm{GE}_{0}, \mathrm{GE}_{2}$ and $\mathrm{GE}_{5}$ respectively and presented in identical aluminum foil in trays simultaneously to avoid possibility of panelist re-evaluating a sample. Necessary precaution were taken to prevent bias of panelists during evaluation by ensuring that the panelists rinse their mouth after tasting each sample and were trained in each stage of organoleptic evaluation, it was also ensured that the panelists were ignorant of the actual samples represented by a code.

\section{Statistical analysis}

The data obtained from proximate and sensory evaluation were subjected to Statistical analysis using Analysis of variance (ANOVA) and Mean Separation [16] with SPSS Window 17.0 Version of Inc., USA.

\section{Results and Discussion}

\section{Proximate analysis}

Results showed that the use of the spices pre-treatment increased nutrients notably the percentage crude protein $(\mathrm{CP})$ content of fish linearly $(\mathrm{p}<0.05)$ from $64.86 \pm 0.01 \%$ in $\mathrm{BP}_{0}$ (control) to $68.80 \pm 0.40 \%$ in $\mathrm{BP}_{5}$ for black pepper experiment while ginger treatments coded $\mathrm{GE}_{0}, \mathrm{GE}_{2}$ and $\mathrm{GE}_{5}$ recorded Crude Protein values of $64.58 \pm 0.03 \%$, $68.37 \pm 0.05 \%$ and $68.63 \pm 0.01 \%$ respectively. Similar observation was recorded when smoked African Lungfish was treated with ginger [7] (Tables 1 and 2). The improved crude protein concentration linearly with spices fortification might be due to additional nutrients inherent in black pepper and ginger which contained crude protein (8.60\%), Ether extract $(15.21 \%)$ and minerals $(A s h=5.21 \%)$ as reported by Nwinuka et al. [17] and Meadow [18]. Similarly, there were significant differences in the concentrations of crude fat, Ash and soluble carbohydrate between the control fish and those treated with extracts from the two spices respectively $(p<0.05)$ but not significantly different in moisture content generally $(p>0.05)$. Also, there was no significant difference $(p>0.05)$ in percentage moisture loss in the fish products from the two spices which are within the range of $65.00 \%$ recommended by Cardinal et al. [19] as shown in Tables 3 and 4 below.

The Ash content of the oven-dried moonfish ranged from 4.06 $\pm 0.13 \%$ and $4.70 \pm 0.01 \%$. These values are higher than $0.40-1.35 \%$ 
Citation: Agbabiaka LA, Kuforiji OA, Egobuike CC (2016) Comparative Studies on the Nutrients, Sensory and Storage Qualities of MoonFish (Citharinus citharus Geoffery Saint-Hilaire 1809) Pre-Treated with Extracts from Two Spices. J Aquac Res Development 7: 398. doi:10.4172/2155-9546.1000398

Page 3 of 5

\begin{tabular}{|c|c|c|c|c|c|}
\hline Samples & Live weight of fish (g) & Dressed Weight (g) & Weight after Total smoking (g) & Weight loss(g) & Weight loss (\%) \\
\hline $\mathrm{BP}_{0}$ & 845 & 716 & 295 & 550.66 & 65.11 \\
\hline $\mathrm{BP}_{2}$ & 860 & 725.6 & 265.31 & 594.69 & 69.15 \\
\hline $\mathrm{BP}_{5}$ & 815 & 691.67 & 264.88 & 550.13 & 67.5 \\
\hline
\end{tabular}

Average weight loss $(\%)=67.26$

$\mathrm{BP}$ : Fish sample treated with $3 \%$ brine solution only (control)

$\mathrm{BP}_{2}$ : Fish sample treated with mixture of $3 \%$ brine and $2 \%$ black pepper

$\mathrm{BP}_{5}$ : Fish sample treated with mi8xture of $3 \%$ brine and $5 \%$ black pepper

Table 1: Mean weight Characteristics of Dried Moon-fish (Citharinus citharus) pretreated with black pepper.

\begin{tabular}{|c|c|c|c|c|c|}
\hline Samples & Live weight of fish (g) & Dressed Weight (g) & Weight after smoking (g) & Total weight loss (g) & (\%) weight loss \\
\hline $\mathrm{GE}_{0}$ & 890 & 751 & 242.26 & 647.74 & 72.78 \\
\hline $\mathrm{GE}_{2}$ & 880 & 745.6 & 307.74 & 572.26 & 65.03 \\
\hline $\mathrm{GE}_{5}$ & 865 & 737.67 & 302.49 & 562.51 & 65.03 \\
\hline
\end{tabular}

Average weight loss $(\%)=67.13$

$\mathrm{GE}_{0}$ : Fish sample treated with $3 \%$ brine solution only (control)

$\mathrm{GE}_{2}$ : Fish sample treated with mixture of $3 \%$ brine and $2 \%$ ginger extract

$\mathrm{GE}_{5}$ : Fish sample treated with mixture of $3 \%$ brine and $5 \%$ ginger extract

Table 2: Weight characteristics of Citharinus citharus pre-treated with ginger and oven-dried.

\begin{tabular}{|c|c|c|c|}
\hline \multicolumn{4}{|c|}{ Concentrations of Black pepper extract } \\
\hline Parameters & $\mathrm{BP}_{0}$ & $\mathrm{BP}_{2}$ & $\mathrm{BP}_{5}$ \\
\hline Moisture \% & $12.77 \pm 0.03^{\mathrm{a}}$ & $12.64 \pm 0.01^{b}$ & $12.290 .01^{\mathrm{c}}$ \\
\hline Protein \% & $64.86 \pm 0.01^{c}$ & $67.86 \pm 0.02^{b}$ & $68.810 .4^{\mathrm{a}}$ \\
\hline Fat \% & $5.52 \pm 0.02^{\mathrm{a}}$ & $4.62 \pm 0.01^{c}$ & $4.79 \pm 0.2^{\mathrm{b}}$ \\
\hline Ash \% & $4.58 \pm 0.02^{\mathrm{a}}$ & $4.06 \pm 0.13^{b}$ & $4.70 \pm 0.01^{a}$ \\
\hline NFE \% & $12.27 \pm 6.02^{\mathrm{a}}$ & $10.82 \pm 0.09^{b}$ & $9.410 .40^{\mathrm{b}}$ \\
\hline
\end{tabular}

Mean and STD scores with different superscript at the same row are significantly different $(P<0.05)$.

$\mathrm{BP}_{0}$ : Fish sample treated with $3 \%$ brine solution only (control)

$\mathrm{BP}_{2}$ : Fish sample treated with mixture of $3 \%$ brine and $2 \%$ black pepper

$\mathrm{BP}_{5}$ : Fish sample treated with mixture of $3 \%$ brine and $5 \%$ black pepper

STD: Standard Deviation

NFE: Nitrogen Free Extract

Table 3: Proximate composition of Moon Fish pre-treated with black pepper extract.

\begin{tabular}{|c|c|c|c|}
\hline \multicolumn{4}{|c|}{ Concentrations of Ginger extract } \\
\hline Parameters & $\mathrm{GE}_{0}$ & $\mathrm{GE}_{2}$ & $\mathbf{G E}_{5}$ \\
\hline Moisture (\%) & $13.22 \pm 0.02^{b}$ & $11.70^{c} \pm 0.11^{c}$ & $13.81 \pm 0.11^{c}$ \\
\hline Protein (\%) & $65.58 \pm 0.03^{b}$ & $68.37 \pm 0.05^{a}$ & $68.630 .01^{\mathrm{a}}$ \\
\hline Fat $(\%)$ & $5.48 \pm 0.02^{\mathrm{a}}$ & $5.41 \pm 0.01^{a}$ & $5.38 \pm 0.01^{a}$ \\
\hline Ash (\%) & $4.67 \pm 0.01^{a}$ & $3.98 \pm 0.19^{c}$ & $4.34 \pm 0.01^{\mathrm{b}}$ \\
\hline NFE (\%) & $10.69 \pm 0.04^{a}$ & $10.53 \pm 0.13^{a}$ & $7.77 \pm 0.01^{c}$ \\
\hline
\end{tabular}

Means plus STD within same row having different superscript differs significantly $(P>0.05)$

$\mathrm{GE}_{0}$ : Fish sample treated with $3 \%$ brine solution only (control)

$\mathrm{GE}_{2}$ : Fish sample treated with mixture of $3 \%$ brine and $2 \%$ ginger extract

$\mathrm{GE}_{5}$ : Fish sample treated with mixture of $3 \%$ brine and $5 \%$ ginger extract

STD: Standard Deviation

NFE: Nitrogen Free Extract

Table 4: Table of proximate composition of moonfish pre-treated with ginger extract.

reported by Abdullahi [20]. This suggests that the extracts of black pepper and ginger did not inhibit mineral content of the fish but improved it. The minerals especially calcium content in a fish product is an indication of the quality of the product [21].

The sensory evaluation revealed that products treated with Black pepper and Ginger extracts retained consumer acceptability in all attributes measured $(p>0.05)$ up to the sixth day (Tables 5 and 6); though, samples treated with Piper guineense retained fairly good and better attributes on the six day comparatively ( $p>0.05)$. Nevertheless, the decline in qualities of the two samples from the fifth day may be probably due to the onset of microbes and degradation of protein/lipid in the muscle that leads to oxidative rancidity resulting to production of hypoxanthine and trimethylamine [22]. The improved shelf live up to 5th day may also be due to action of heat that reduced water activity and impaired the action of spoilage microbes $[19,23]$. The general acceptability in all the sensory parameters indicated that the spices might have inherent chemical compounds responsible for the pleasant colour, taste and flavor/aroma in oven-dried products [12,13].

Dressed weight $=$ Carcass weight-weight of offals

Total weight Loss=Live Weight/Carcass weight-weight after smoking

$\%$ weight loss $=\frac{\text { Total weight loss }}{\text { Live wieght of fish }} \times \frac{100}{1}$ 
Citation: Agbabiaka LA, Kuforiji OA, Egobuike CC (2016) Comparative Studies on the Nutrients, Sensory and Storage Qualities of MoonFish (Citharinus citharus Geoffery Saint-Hilaire 1809) Pre-Treated with Extracts from Two Spices. J Aquac Res Development 7: 398. doi:10.4172/2155-9546.1000398

Page 4 of 5

\begin{tabular}{|c|c|c|c|c|c|c|c|c|c|}
\hline \multirow[t]{2}{*}{ Parameters } & \multirow[t]{2}{*}{ Samples } & \multicolumn{8}{|c|}{ Storage Period (Days) } \\
\hline & & 1 & 2 & 3 & 4 & 5 & 6 & 7 & LSD \\
\hline \multirow[t]{3}{*}{ Appearance } & $\mathrm{GE}_{0}$ & $7.13^{\mathrm{ab}}$ & $7.88^{\mathrm{a}}$ & $7.63^{\mathrm{ab}}$ & $6.59^{b c}$ & $6.25^{c}$ & $3.63^{d}$ & $1.13^{\mathrm{e}}$ & 0.57651 \\
\hline & $\mathrm{GE}_{2}$ & $7.63^{\mathrm{a}}$ & $7.88^{\mathrm{a}}$ & $6.5^{\mathrm{bc}}$ & $6.25^{\mathrm{b}}$ & $5.88^{b}$ & $3.63^{c}$ & $1.13^{d}$ & 0.63735 \\
\hline & $\mathrm{GE}_{5}$ & $8.13^{a}$ & $8.00^{\mathrm{a}}$ & $7.50^{\mathrm{a}}$ & $6.26^{b}$ & $5.88^{b}$ & $3.00^{c}$ & $1.13^{d}$ & 0.60288 \\
\hline \multirow[t]{3}{*}{ Aroma } & $\mathrm{GE}_{0}$ & $6.50^{b}$ & $7.88^{\mathrm{a}}$ & $6.76^{b}$ & $6.76^{\mathrm{b}}$ & $4.88^{c}$ & $3.26^{d}$ & $3.38^{d}$ & 0.62504 \\
\hline & $\mathrm{GE}_{2}$ & $7.26^{\mathrm{a}}$ & $6.76^{\mathrm{ab}}$ & $6.75^{a}$ & $6.00^{\mathrm{ab}}$ & $4.88^{b}$ & $3.63^{c}$ & $3.13^{c}$ & 0.80571 \\
\hline & $\mathrm{GE}_{5}$ & $7.50^{\mathrm{a}}$ & $7.00^{\mathrm{ab}}$ & $6.88^{\mathrm{ab}}$ & $6.00^{\mathrm{bc}}$ & $5.38^{c}$ & $3.75^{d}$ & $3.25^{d}$ & 0.61721 \\
\hline \multirow[t]{3}{*}{ Taste } & $\mathrm{GE}_{0}$ & $7.38^{\mathrm{a}}$ & $7.63^{a}$ & $7.00^{\mathrm{a}}$ & $6.63^{a}$ & $5.13^{\mathrm{b}}$ & $3.50^{c}$ & $1.75^{d}$ & 0.65835 \\
\hline & $\mathrm{GE}_{2}$ & $7.50^{\mathrm{a}}$ & $7.00^{\mathrm{ab}}$ & $6.63^{\mathrm{ab}}$ & $6.13^{b}$ & $5.50^{\mathrm{bc}}$ & $3.88^{c}$ & $1.60^{d}$ & 0.69846 \\
\hline & $\mathrm{GE}_{5}$ & $7.88^{\mathrm{a}}$ & $7.38^{a}$ & $7.38^{a}$ & $6.13^{b}$ & $5.63^{b}$ & $4.13^{c}$ & $2.00^{d}$ & 0.61721 \\
\hline \multirow[t]{3}{*}{ Texture } & $\mathrm{GE}_{0}$ & $6.88^{\mathrm{ab}}$ & $7.50^{\mathrm{a}}$ & $7.38^{\mathrm{a}}$ & $6.26^{\mathrm{ab}}$ & $5.75^{b}$ & $2.88^{c}$ & $1.76^{d}$ & 0.57819 \\
\hline & $\mathrm{GE}_{2}$ & $7.00^{\mathrm{a}}$ & $7.50^{\mathrm{a}}$ & $6.63^{\mathrm{ab}}$ & $5.50^{\text {bc }}$ & $4.88^{c}$ & $3.25^{d}$ & $2.37^{d}$ & 0.60929 \\
\hline & $\mathrm{GE}_{5}$ & $7.50^{\mathrm{a}}$ & $6.38^{a b}$ & $6.63^{\mathrm{ab}}$ & $5.75^{b}$ & $5.25^{b}$ & $3.25^{c}$ & $2.75^{c}$ & 0.67534 \\
\hline
\end{tabular}

Means within rows with different superscripts differ significantly $(P<0.05)$

$\mathrm{GE}_{0}$ : Fish sample treated with $3 \%$ brine solution only (control)

$\mathrm{GE}_{2}$ : Fish sample treated with mixture of $3 \%$ brine and $2 \%$ ginger extract

$\mathrm{GE}_{5}$ : Fish sample treated with mixture of $3 \%$ brine and $5 \%$ ginger extract

Table 5: Organoleptic attributes of oven-dried moonfish with ginger extract pre-treatment.

\begin{tabular}{|c|c|c|c|c|c|c|c|c|c|}
\hline \multirow[t]{2}{*}{ Parameters } & \multirow[t]{2}{*}{ Samples } & \multicolumn{8}{|c|}{ Storage Period (Days) } \\
\hline & & 1 & 2 & 3 & 4 & 5 & 6 & 7 & LSD \\
\hline \multirow[t]{3}{*}{ Appearance } & $\mathrm{BP}_{0}$ & $7.00^{\mathrm{ab}}$ & $8.29^{a}$ & $7.57^{\mathrm{a}}$ & $6.29^{\mathrm{b}}$ & 6. $29^{b}$ & $4.00^{c}$ & $1.14^{d}$ & 0.52651 \\
\hline & $\mathrm{BP}_{2}$ & $7.57^{\mathrm{a}}$ & $7.71^{\mathrm{a}}$ & $7.14^{\mathrm{a}}$ & $6.86^{\mathrm{ab}}$ & $7.00^{\mathrm{ab}}$ & $5.00^{\mathrm{bc}}$ & $1.14^{\mathrm{d}}$ & 0.58703 \\
\hline & $\mathrm{BP}_{5}$ & $7.57^{\mathrm{a}}$ & $7.00^{\mathrm{ab}}$ & $7.57^{\mathrm{a}}$ & $7.00^{\mathrm{ab}}$ & $7.29^{a}$ & $6.43^{b}$ & $1.14^{d}$ & 0.50218 \\
\hline \multirow[t]{3}{*}{ Aroma } & $\mathrm{BP}_{0}$ & $5.86^{c}$ & $7.57^{\mathrm{a}}$ & $6.86^{\mathrm{ab}}$ & $6.43^{\mathrm{b}}$ & $6.29^{b}$ & $4.00^{c}$ & $1.14^{\mathrm{d}}$ & 0.65335 \\
\hline & $\mathrm{BP}_{2}$ & $7.00^{\mathrm{ab}}$ & $6.43^{\mathrm{b}}$ & $7.29^{a}$ & $6.57^{\mathrm{ab}}$ & $6.57^{\mathrm{ab}}$ & $5.00^{c}$ & $1.86^{d}$ & 0.68346 \\
\hline & $\mathrm{BP}_{5}$ & $7.43^{\mathrm{a}}$ & $7.00^{\mathrm{ab}}$ & $6.43^{\mathrm{b}}$ & $6.43^{\mathrm{b}}$ & $6.43^{b}$ & $5.42^{c}$ & $1.71^{\mathrm{d}}$ & 0.67814 \\
\hline \multirow[t]{3}{*}{ Texture } & $\mathrm{BP}_{0}$ & $6.14^{\mathrm{b}}$ & $7.28^{a}$ & $7.00^{\mathrm{ab}}$ & $6.29^{\mathrm{b}}$ & $4.43^{c}$ & $4.00^{c}$ & $2.43^{d}$ & 0.62004 \\
\hline & $\mathrm{BP}_{2}$ & $6.71^{\mathrm{ab}}$ & $6.86^{\mathrm{ab}}$ & $7.43^{\mathrm{a}}$ & $6.14^{\mathrm{b}}$ & $5.36^{\mathrm{bc}}$ & $4.71^{c}$ & $1.71^{\mathrm{d}}$ & 0.80117 \\
\hline & $\mathrm{BP}_{5}$ & $6.71^{\mathrm{ab}}$ & $7.00^{\mathrm{ab}}$ & $7.00^{\mathrm{ab}}$ & $6.14^{\mathrm{b}}$ & $6.71^{\mathrm{ab}}$ & $5.57^{\mathrm{bc}}$ & $1.57^{d}$ & 0.79721 \\
\hline \multirow[t]{3}{*}{ Taste } & $\mathrm{BP}_{0}$ & $6.14^{b}$ & $7.33^{a}$ & $7.29^{a}$ & $6.14^{b}$ & $5.14^{\mathrm{bc}}$ & $4.71^{c}$ & $1.71^{d}$ & 0.52819 \\
\hline & $\mathrm{BP}_{2}$ & $7.00^{\mathrm{ab}}$ & $6.86^{\mathrm{ab}}$ & $7.14^{a}$ & $6.43^{b}$ & $6.71^{\mathrm{ab}}$ & $4.71^{c}$ & $1.71^{\mathrm{d}}$ & 0.60428 \\
\hline & $\mathrm{BP}_{5}$ & $6.86^{\mathrm{ab}}$ & $7.85^{\mathrm{a}}$ & $6.71^{\mathrm{ab}}$ & $5.71^{c}$ & $6.43^{b}$ & $6.14^{b}$ & $1.43^{d}$ & 0.67036 \\
\hline
\end{tabular}

Mean scores with different superscript along the columns are significantly different $(P<0.05)$

$\mathrm{BP}:$ Fish sample treated with $3 \%$ brine solution only (control)

$\mathrm{BP}_{2}$ : Fish sample treated with mixture of $3 \%$ brine and $2 \%$ black pepper

$\mathrm{BP}_{5}$ : Fish sample treated with mi8xture of $3 \%$ brine and $5 \%$ black pepper

Table 6: Organoleptic assessment of black pepper pre-treated oven dried moonfish.

\section{Conclusion}

However, the linear increment in nutrients assay with spice concentrations have further shown the positive value-addition attributes of these two spices. Hence, results from this study clearly recommend the use of these spices (Ginger and Black pepper) as value addition in fish processing to enhance storage and nutritional qualities.

\section{References}

1. Food and Agricultural Organization (2007) The state of World Fisheries and Aquaculture. FAO Fisheries Department, Rome, Italy.

2. http://www.thisdaylive.com/articles/aquaculture-as-path-to-thrivingagriculture/124614/.

3. United State Agency for International Development (2015) USAID funded project increases fish yield in Nigeria. Nigerian Vanguard Newspaper: Retrieved on Tuesday March 10th, 2015.

4. Oota L (2012) Is Nigeria committed to fish production. Accessed online $20^{\text {th }}$ October.

5. Nwiro E (2012) Fish farming a lucrative business. Accessed online $20^{\text {th }}$ October 2012.

6. Agbabiaka LA, Amadi AS, Madubuko CU, Nwankwo FC, Ojukannaiye AS (2012) Assessment of nutrients and sensory qualities of brine pre-treated catfish smoked with two different woods. African Journal of Food Science 6: 245-248.
7. Agbabiaka LA (2015) Assessment of nutrients and microbial evaluation of ginger pre-treated smoked African lungs-fish (Protopterus annecten OWEN, 1883) Tropical Agriculture (In press).

8. Omojowo FS, Ihuahi JA (2010) Preliminary report on the effects of different sauces on pouched Tilapia products. New York Science Journal 3: 83-86.

9. Gupta SK, Gupta PC (2006) General and Applied Ichthyology (Fish and Fisheries). S. Chand and Co. Ltd publishers, Ram Nagar, New Delhi, India.

10. Ahmed RS, Sharma SB (1997) Biochemical studies on combined effect of garlic (Allium satium Linn) and ginger (Zingiber officinale) in albino rats. Ind $J$ Exp Biol 35: 841-843.

11. Negbenebor CA, I Nkama, P Sopade (1999) Raw material supply for fish and animal processing industries. In: Proceedings of a workshop organized by the North-East chapter of NIFST, Maiduguri, Nigeria. 12-24.

12. Bhandary CS (1993) Effect of spice treatment on lipid oxidation in smoked mackerel (Scomber scomber) FAO fisheries.

13. Amadi EC (2001) Antioxidant Effect of Oleoresin of some local Spices. Black pepper (Piper guineense), garlic (Allium satium), Nchuanwu (Ocimum gritininum) and Ehuru (Monodora myristica). Proceedings of $25^{\text {th }}$ Annual Conference of NIFST.

14. AOAC (2000) Association of Official Analytical Chemist. Official methods of Analysis, 17th edition. Washington DC.

15. Afolabi OA, Arawomo OA, Oke OL (1984) Quality changes of Nigeria 
Citation: Agbabiaka LA, Kuforiji OA, Egobuike CC (2016) Comparative Studies on the Nutrients, Sensory and Storage Qualities of MoonFish (Citharinus citharus Geoffery Saint-Hilaire 1809) Pre-Treated with Extracts from Two Spices. J Aquac Res Development 7: 398. doi:10.4172/2155-9546.1000398

Traditionally processed freshwater fish species. I. Nutritive and organoleptic changes. J Food Technol 19: 333-340

16. Duncan DB (1955) Multiple range and multiple $F$ tests. Biometrics 11:1-42.

17. Nwinuka NM, Ibeh GO, Ekeke GI (2005) Proximate Composition and levels of some toxicants in four commonly consumed spices. Journal of Applied Sciences and Environmental Management 9:150-155.

18. Meadows AB (1988) Ginger processing for food and Industry. Federal Institute of Indus. Res, Oshodi, Lagos, Nigeria.

19. Cardinal M, Knockaert C, Torrissen O, Sigurgisladottir S, Morkore T, et al. (2001) Relation of smoking parameters to the yield colour and sensory quality of smoked Atlantic salmon (Salmo salar). Food Res Int 34: 537-550.
20. Abdullahi SA (2001) Investigation of Nutritional status of Chrysichthys nigrodigitatus, Bagrus filamentous and Auchenoglanis occidentals: Family Barigdae. Journal of Arid zone Fisheries 1: 39-50.

21. Clucas IJ, Ward AR (1996) Postharvest fisheries development: a guide to Handling preservation, processing and Quality. Chatham Maritime, Kent ME44TB, United Kingdom

22. Johnson WA, Nicholson FJ, A Roger (1994) Freezing and refrigerated storage in fisheries. Stroud Series. FAO Fisheries Technical Paper.

23. Abolagba OJ, Osifo SJ (2004) The effect of smoking on the chemical composition and keeping qualities of catfish (Heterobranchus bidorsalis) using two energy sources. Journal of Agric. Forestry and Fisheries 5: 27-30. 